\title{
Check dams exacerbate the effects of high flow on aquatic insect communities in tropical stream of northern Thailand
}

\author{
Phuchiwan Suriyawong $^{\mathrm{a}, *}$, Decha Thapanya ${ }^{\mathrm{b}}$, Elizabeth A. Bergey ${ }^{\mathrm{c}}$, Porntip Chantaramongkol ${ }^{\mathrm{b}}$ \\ a Environmental Science Program, Faculty of Science, Chiang Mai University, Chiang Mai 50200 Thailand \\ b Department of Biology, Faculty of Science, Chiang Mai University, Chiang Mai 50200 Thailand \\ c Oklahoma Biological Survey, University of Oklahoma, Norman, OK 73019, USA
}

*Corresponding author, e-mail: phuchiwan_s@cmu.ac.th

Received 6 Mar 2017

Accepted 20 Jun 2018

\begin{abstract}
Check dams have been widely constructed in Thai streams and our study examined effects of dam-caused flow regime changes on aquatic insect communities. The flow regime of Huay Kaew Stream in Doi Suthep-Pui National Park, Chiang Mai, Thailand was separated into two periods: high flow and low flow periods, which characterize the natural flow dynamics in tropical streams. The sampling sites in three altitudes (1500, 900, and $500 \mathrm{~m}$ asl.) of the stream showed a similar trend in the effects of check dams during high flow. High discharge reduced the density of aquatic insects but this reduction was locally greater near check dams. Higher changes in water velocity at dammed sites caused greater decreases in aquatic insect community abundance because of alternating accumulation and dislodgement of fine sediment and leaf pack habitat below dams. An increase in cobble habitat because of dam erosion below a non-permanent check dam helped mitigate the effects of high flow and flow disturbance on aquatic insect density. A high density of check dams likely affects streambed structure and insect composition within the stream system.
\end{abstract}

KEYWORDS: altitude, Doi Suthep, microhabitat, mountain stream

\section{INTRODUCTION}

Natural stream flow and unfragmented stream systems are necessary to maintain native stream biotas $^{1}$. The non-uniform flow of natural streams produces unique hydraulic characteristics along streams that constitute different habitats for different groups of aquatic organisms ${ }^{2}$. The continuity of stream flow allows the transfer of nutrients and food sources to downstream organisms. The continuous flow also supports downstream dispersal of aquatic biota, which enhances gene flow and genetic diversity ${ }^{3,4}$. Additionally, the natural seasonal flow pattern, which affects the movement of water and materials, organizes community structure based on the ability of species to adapt to flow variability and habitat restructuring, which in turn support high biodiversity ${ }^{5,6}$. The periodic changes in flow associated with seasonal flows is also needed for nutrient retention and cycling ${ }^{6}$. Dams and the resultant changes in flow dynamics can disturb aquatic communities in a number of ways. Changes in flow regime alter habitat dynamics, which influence the distribution and abundance of aquatic organisms ${ }^{5}$. Dams can form barriers to the movement of organisms within drainage networks, disrupting organismal and genetic connections among populations, which are the basis of the metapopulation concept ${ }^{7}$. The global concern of water scarcity because of climate change encourages engineered solutions for water storage - especially in the construction of dams. The number of dams has rapidly increased over the last six decades and more are being constructed to cope with issues of water shortage and flood control ${ }^{8}$. Furthermore, widespread interest in hydropower spurs more dam construction to help meet the increasing energy demand and reduce dependence on fossil fuels, in reaction to the global concern to reduce the causes of climate change ${ }^{7,9}$. Dam construction exacerbates the impacts of climate change on rivers by causing river fragmentation and flow regulation. Changes in the frequency and magnitude of rainfall may produce more frequent flash floods that result in rapid drainage, which is obstructed by dams. Conversely, not releasing water from dams during periods of reduced rainfall can impair downstream biota ${ }^{10}$. 
In addition to the large dams that are built for water storage and hydropower, small dams are widely found in streams for smaller-scale water storage, water diversion and flood control. Although the ecological effects of small dams in temperate zones are well known, tropical studies are fewer and are still needed ${ }^{11-13}$. Although tropical and temperate streams seem to have similar ecological process (especially high-altitude tropical streams, which are more similar to temperate systems than are lowland tropical streams), tropical ecosystems receive more sunlight, have higher water temperature and have lower climatic variation, which support a wider range of biodiversity and ecosystems compared to temperate streams ${ }^{11,14,15}$. Hence studies on stream structure and function in temperate streams might not be directly applicable to tropical streams. Besides the latitudinal difference, ecological processes can vary at the local scale because of variation of local climatic conditions, land use and biogeography ${ }^{11,14,15}$. Improved understanding of tropical stream ecology enhances creating appropriate management mitigation for flow disturbance caused by humans, both directly and through climate change ${ }^{16}$.

In Thailand, many check dams or small dams have been constructed, especially since 2004, for water and sediment storage and flow reduction. A series of check dams is generally produced along a stream. This is the case in Huay Kaew Stream, which contains numerous check dams (more than forty check-dams along the six kilometres of study section). The resulting high density of check dams in tributaries of rivers may culminate in large downstream changes. For example, alteration of a flow regime disturbs both the habitat and life history of aquatic organisms and provides conditions that may be favourable to invasive species ${ }^{17}$. A previous study on check dams in Huay Kaew Stream found such habitat changes; specifically, a reduction in habitat diversity and macroinvertebrate diversity above dams, which was linked to greater effects of seasonal floods ${ }^{18,19}$, whereas areas directly below dams were less affected.

Aquatic insects are a speciose group, comprising $60 \%$ of freshwater animal species, and are critical food web components, converting algae and detritus into prey for fish and other animals ${ }^{20}$. Aquatic insects are widely used for biomonitoring in streams and rivers, as community composition and abundance indicate water quality by integrating stream conditions, whereas physicochemical measurements indicate water conditions only at the

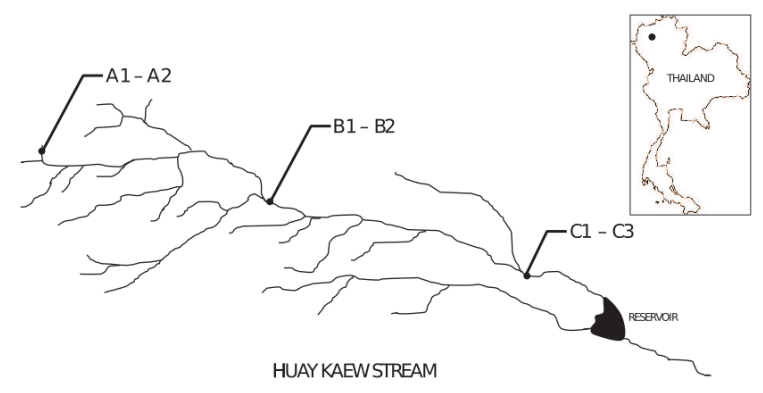

Fig. 1 Sampling sites on Huay Kaew stream, a tributary of Ping river in Chiang Mai Province, northern Thailand. Site A, B and C located at altitude about 1500, 900, and $500 \mathrm{~m}$, respectively. A1, B1 and C1 were undammed sites and located upstream of their corresponding dammed sites.

moment of measurement ${ }^{21}$. Biomonitoring using aquatic insects can be relatively low cost, an important consideration given the universal problem of inadequate funding for monitoring ${ }^{7}$.

Mountainous terrain brings an added dimension to stream studies because altitude and the associated slope influence flow patterns, habitat structure and trophic-related processes ${ }^{1,22}$. Aquatic insects in different altitudes may have different responses to anthropogenic disturbance ${ }^{23}$. Taxa richness decreases with altitude in Nepalese and Ecuadorian streams ${ }^{24}$. Indeed, the aquatic insects of highland streams are more similar to temperate streams than to lowland Ecuadorian streams; for example some taxonomic groups, such as Hydropsychidae and Gomphidae, are classed as 'lowland' species' and are common components of temperate faunas ${ }^{25,26}$.

This survey-based study examined how small check dams influenced physiochemical conditions and aquatic insect community composition, especially with respect to low versus high flow periods and variation with altitude. Specific hypotheses tested were (1) stream characteristics and insect assemblages are impacted by high flows; (2) checkdams alter habitats and, consequently, insect assemblages; (3) the combination of high flow and the presence of check dams impacts insect assemblages downstream of dams more than assemblages in undammed areas; (4) different altitudes provide different habitats and consequently different insect assemblages, but these assemblages were similarly affected by high flows (including with respect to check dams). The study was sited along a single stream system, Huay Kaew Stream, which is the source of water for Chiang Mai University. 


\section{MATERIALS AND METHODS}

Study sites were located at three altitudes (1500, 900, and $500 \mathrm{~m}$ asl.) in the Huay Kaew Stream in Doi Suthep-Pui National Park (Fig. 1). Each altitude included undammed and dammed sites. The undammed sites at each altitude were located upstream from the check dams beyond the effects of the dams and where background environment features were similar to those of the dammed sites. The dammed sites were located downstream of each check dam.

Site A (at altitude $1500 \mathrm{~m}$ ) was located on a first-order stream that is usually $1 \mathrm{~m}$ wide and $5 \mathrm{~cm}$ deep. The check dam at this site is made of ferroconcrete with a $5 \mathrm{~m}$ length and a $1 \mathrm{~m}$ height. A pipe from the top of reservoir drains water across the check dam into the outflow downstream of the dam. The undammed site (A1; $18^{\circ} 49^{\prime} 33.7^{\prime \prime} \mathrm{N}$ $\left.98^{\circ} 53^{\prime} 27.6^{\prime \prime} \mathrm{E}\right)$ was located about $320 \mathrm{~m}$ upstream from the dammed site (A2).

Site B was near a bedrock waterfall on the third order stream at an altitude of $900 \mathrm{~m}$. The stream section was about $2 \mathrm{~m}$ wide and $0.1 \mathrm{~m}$ in depth. The undammed site (B1) was situated $15 \mathrm{~m}$ upstream from the dammed site (B2; $18^{\circ} 49^{\prime} 5.3^{\prime \prime} \mathrm{N}$ $98^{\circ} 55^{\prime} 58^{\prime \prime} \mathrm{E}$ ), which is downstream of a rock-fill dam that has a height of $1 \mathrm{~m}$ and a width of $9 \mathrm{~m}$. Water drains to site B2 by seeping under the check dam.

Site C was located at altitude $500 \mathrm{~m}$ on the third order stream, where the width was about 1$7 \mathrm{~m}$, with a depth of 1-3 m. The undammed site $\left(\mathrm{C} 1 ; 18^{\circ} 48^{\prime} 55.5^{\prime \prime} \mathrm{N} 98^{\circ} 56^{\prime} 2.3^{\prime \prime} \mathrm{E}\right)$ was near a bedrock waterfall, $174 \mathrm{~m}$ upstream of the check dam site (C2). The dam is made of ferroconcrete and has a $1 \mathrm{~m}$ height and a $10 \mathrm{~m}$ length. Site C3 was at a smaller check dam located $146 \mathrm{~m}$ downstream of C2. This downstream check dam was made of rock and concrete (a concrete-faced rock-fill dam) with $0.5 \mathrm{~m}$ height and $5 \mathrm{~m}$ length. Water crosses both check dams by surface overflow.

Discharge or the flow rate, which is water volume per time, was calculated from the stream cross-sectional area and water velocity, which was monthly measured by a velocity meter (Global Water FP101). Discharge among all sampling sites was separated into two periods. High flow in the study stream refers to the periods with an average discharge greater than $1 \mathrm{~m}^{3} / \mathrm{s}$, which occurred during the study period in June and August-December 2011 and in January 2012. Air and water temperature, as well as percentage of canopy cover were also measured. Recorded water measurements were conductivity, total dissolved solid (TDS), pH, turbidity, dissolved oxygen (DO) and biochemical oxygen demand (BOD). Data on nutrient concentrations included ammonia-nitrogen, nitrate-nitrogen and orthophosphate concentration. All physicochemical characteristics at the seven sampling sites were recorded in triplicate and averaged for each monthly sampling event. Aquatic insects were collected monthly between March 2011 and February 2012 using a pond net with $0.5 \mathrm{~mm}$ mesh to collect a streambed area of $0.08 \mathrm{~m}^{2}$. Ten samples at each site were taken in proportion to the area of each habitat in a site. The proportion of habitats in the site was monthly recorded. Seven habitats were identified: clay, sand, gravel, cobble, boulder, streamside vegetation and leaf packs. Samples from each habitat were separated. Samples were preserved in $70 \%$ ethanol for later sorting and aquatic insect identification in the laboratory mainly followed Dudgeon ${ }^{35}$. The collected data was analysed by $\mathrm{R} 3.4 .2^{27}$.

To investigate the effects of high flow on physicochemical conditions, differences in monthly data between low and high flow periods were tested using the non-parametric Wilcoxon signed rank test because of the non-normal distribution of the data.

The influence of check dams on water velocity was tested by comparing monthly velocity between dammed and undammed sites using a Wilcoxon signed rank test. Because of the high range of velocity, especially among different altitudes, velocity at each altitude was analysed separately. Because water velocity affects habitat composition, the linear relationship between monthly velocity and the proportion of unstable habitat was tested by regression analysis.

Effects of water flow and dams on insect density were analysed using linear mixed-effects models. Density was logarithmically transformed to approximate normal distribution, as tested with the Shapiro-Wilk statistic. Flow periods (high and low) and dam conditions (dammed and undammed sites) were fitted as the fixed factors and site was fitted as a random factor. The likelihood ratio test was used to attain a $p$-value for finding significant effects of high flow and dam. Regression analysis was use to reveal linear relationships between monthly discharge and (logarithmically transformed) insect density.

To test whether high flow differentially affected aquatic insect density at dammed versus undammed sites, densities at low flow versus high flow periods for both dammed and undammed sites were analysed using a two-way $\chi^{2}$-test for each altitude. 

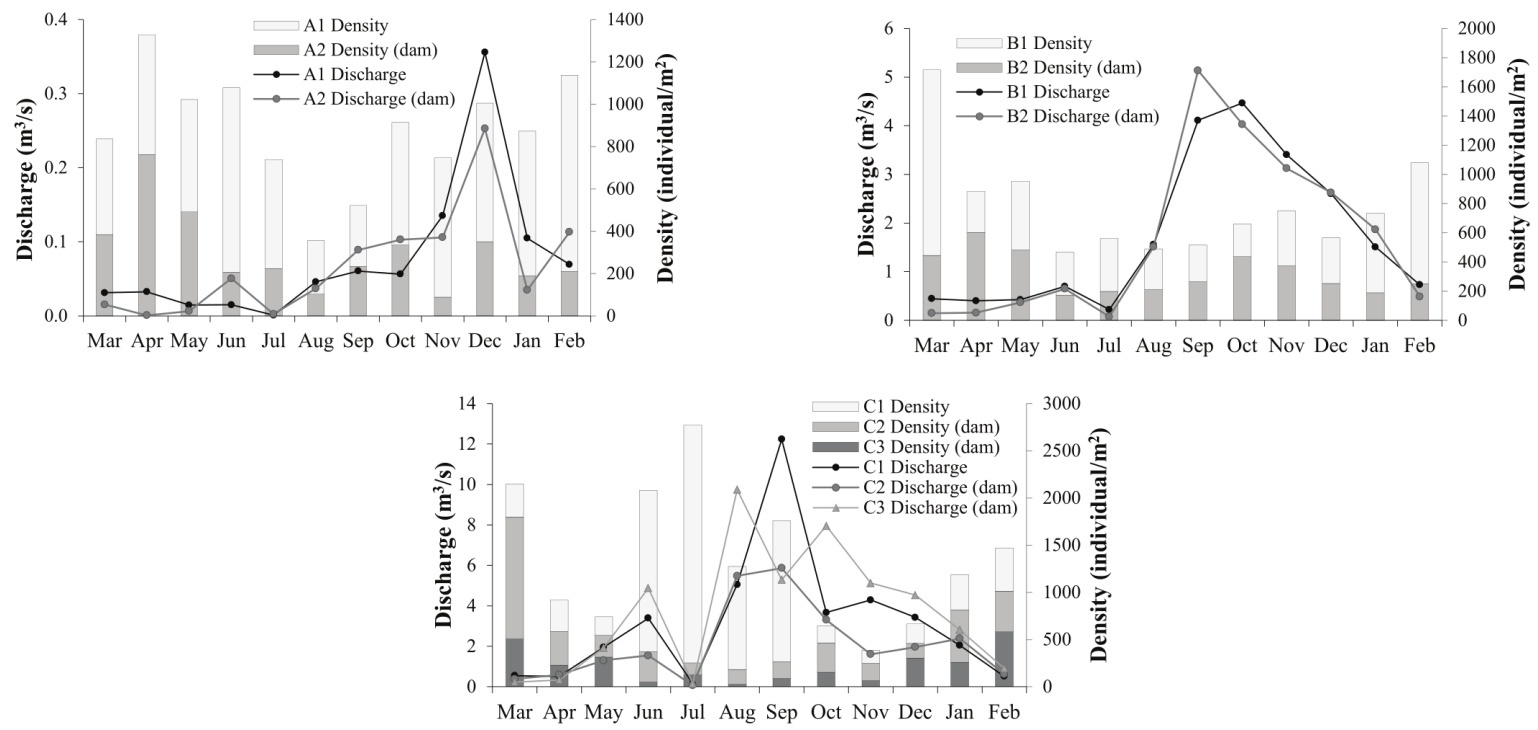

Fig. 2 Monthly discharge and insect density at each sampling site. Site A1 and A2 are located at an altitude of $1500 \mathrm{~m}$ (a), whereas site B (includes B1 and B2) and C (includes C1, C2 and C3) are situated at altitudes of $900 \mathrm{~m}$ (b) and $500 \mathrm{~m}$ (c), respectively. Dammed sites (sites A2, B2 and C2) have lower average discharge and total insect density than their corresponding undammed sites (A1, B1 and C1, respectively) but site C3 showed a higher averaged discharge than the undammed site (C1).

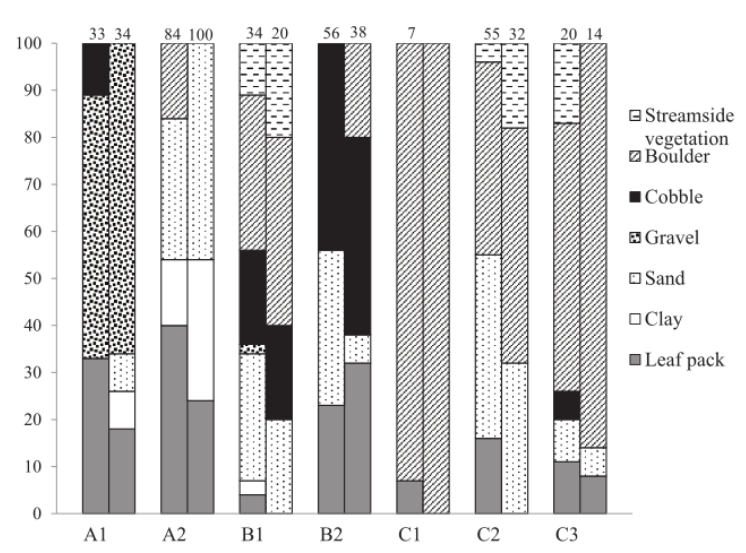

Fig. 3 Habitat structure at each sampling site shows differences between dammed (A2, B2 C2 and C3) and undammed (A1, B1 and C1) sites and between low (left bar) and high (right bar) flow periods. The numbers above the bars are the percentage of unstable habitats, as indicated by the percentage of clay, sand and leaf pack habitats among all sampled habitats. Dammed sites had a higher percentage of unstable habitats than their corresponding undammed sites.

To test the hypothesis that insect composition varied with altitude but that the effects of flow changes were similar among altitudes, monthly abundance of aquatic insects during low and high flow periods at each altitude were square-root transformed, standardized (by Wisconsin-style double standardization) and then used to generate a graphical representation using non-metric multidimensional scaling analysis (NMDS) with Bray-Curtis distance.

\section{RESULTS}

Average discharge of the study stream during high flow periods was six-fold higher than during low flow periods. September had the highest discharge, whereas the lowest discharge was in July when rainfall ceased. Discharge tended to increase with lower altitude (Fig. 2) and greater stream order. The discharge was similar between dammed and undammed sites at two altitudes (1500 m: sites A12 and $900 \mathrm{~m}$ : sites B1-2) but varied among the sites at the lowest altitude (C1-3) (Fig. 2). Streamflow of sites A2 and B2 was continuous across the dams (through a pipe drain and seepage under the dam), whereas water overflowed the dams at sites $\mathrm{C} 2$ and C3.

Each site differed in the habitats available for aquatic insects (Fig. 3). At site A (1500 m), the streambed of the undammed site was mainly gravel and leaf pack, and small areas of clay and sand habitats were primarily present after the high rain- 

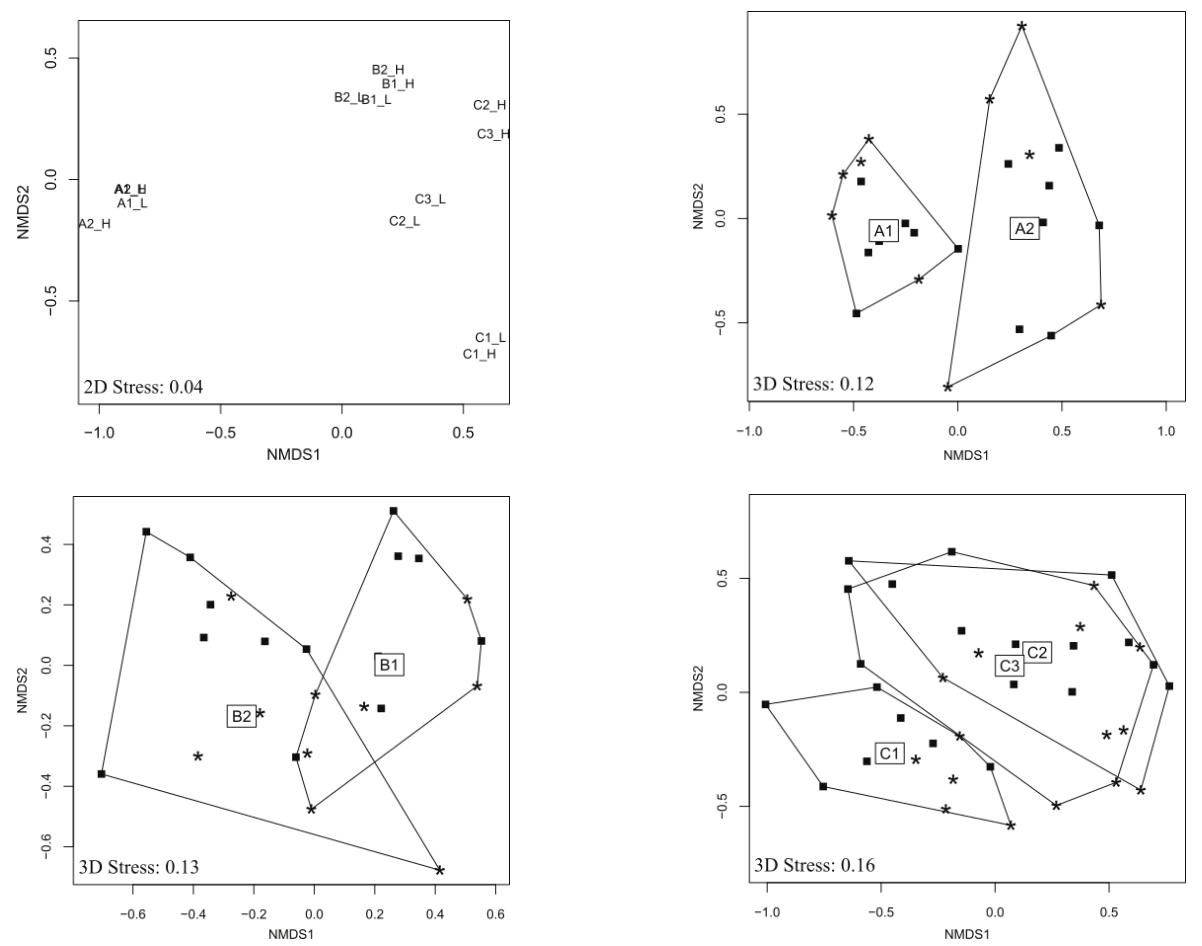

Fig. 4 Non-metric multidimensional scaling plot shows ordination of aquatic insect communities at each site during low $(\mathrm{L}, \star)$ and high $(\mathrm{H}, \boldsymbol{\square})$ flow periods. Bray-Curtis distance and square-root transformation were used for the ordination. Insect assemblages differed by altitude (a). The undammed sites (A2, B2, C2 and C3) had a different insect composition from the corresponding dammed sites $(b, c, d)$.

Table 1 Physicochemical conditions of each site in Mar-May, July and February were averaged as the low flow data, which high flow data came from the average values in June and August-January.

\begin{tabular}{|c|c|c|c|c|c|c|c|c|c|c|c|c|c|}
\hline Sites & $\begin{array}{l}\text { Flow } \\
\text { period }\end{array}$ & $\begin{array}{l}\text { Disch. } \\
\left(\mathrm{m}^{3} / \mathrm{s}\right)\end{array}$ & $\begin{array}{c}\text { WaterT. } \\
\left({ }^{\circ} \mathrm{C}\right)\end{array}$ & $\begin{array}{c}\text { Canopy } \\
(\%)\end{array}$ & $\begin{array}{l}\text { Conduct.* } \\
(\mu S / \mathrm{cm})\end{array}$ & $\begin{array}{l}\text { TDS* } \\
(\mathrm{mg} / \mathrm{l})\end{array}$ & $\begin{array}{l}\text { Turb. } \\
\text { (FTU) }\end{array}$ & $\mathrm{pH}^{*}$ & $\begin{array}{c}\mathrm{DO}^{*} \\
(\mathrm{mg} / \mathrm{l})\end{array}$ & $\begin{array}{c}\text { BOD } \\
(\mathrm{mg} / \mathrm{l})\end{array}$ & $\begin{array}{l}\mathrm{NH}_{3-} \mathrm{N} \\
(\mathrm{mg} / \mathrm{l})\end{array}$ & $\begin{array}{l}\mathrm{NO}_{3-} \mathrm{N} \\
(\mathrm{mg} / \mathrm{l})\end{array}$ & $\begin{array}{c}\mathrm{PO}_{4}^{3-} \\
(\mathrm{mg} / \mathrm{l})\end{array}$ \\
\hline \multirow[t]{2}{*}{ A1 } & low & 0.077 & 18.4 & 96 & $39.7^{\mathrm{a}}$ & $20.7^{\mathrm{a}}$ & 13 & $5.91^{\mathrm{a}}$ & $6.26^{\mathrm{a}}$ & 0.88 & 0.06 & 0.8 & 0.09 \\
\hline & high & & 18.9 & 85 & $37.0^{\mathrm{b}}$ & $19.7^{\mathrm{b}}$ & 12 & $5.55^{\mathrm{b}}$ & $6.62^{\mathrm{b}}$ & 0.54 & 0.05 & 1.1 & 0.08 \\
\hline \multirow[t]{2}{*}{ A2 } & low & 0.068 & 18.5 & 95 & $30.7^{\mathrm{a}}$ & $16.4^{\mathrm{a}}$ & 20 & $5.80^{\mathrm{a}}$ & $6.63^{\mathrm{a}}$ & 1.84 & 0.05 & 0.9 & 0.32 \\
\hline & high & & 18.6 & 92 & $29.6^{b}$ & $15.8^{\mathrm{b}}$ & 17 & $5.65^{\mathrm{b}}$ & $7.10^{\mathrm{b}}$ & 0.80 & 0.07 & 1.0 & 0.05 \\
\hline \multirow[t]{2}{*}{ B1 } & low & 1.714 & 19.7 & 91 & $24.6^{\mathrm{a}}$ & $13.3^{\mathrm{a}}$ & 12 & $6.12^{\mathrm{a}}$ & $8.12^{\mathrm{a}}$ & 0.96 & 0.10 & 1.1 & 0.12 \\
\hline & high & & 19.2 & 80 & $24.1^{\mathrm{b}}$ & $12.8^{\mathrm{b}}$ & 14 & $6.00^{\mathrm{b}}$ & $7.94^{\mathrm{b}}$ & 0.16 & 0.07 & 1.0 & 0.08 \\
\hline \multirow[t]{2}{*}{ B2 } & low & 1.682 & 19.7 & 88 & $26.3^{a}$ & $14.1^{\mathrm{a}}$ & 14 & $6.07^{a}$ & $7.73^{\mathrm{a}}$ & 1.27 & 0.09 & 0.9 & 0.09 \\
\hline & high & & 19.2 & 88 & $24.4^{\mathrm{b}}$ & $12.9^{\mathrm{b}}$ & 17 & $5.84^{b}$ & $8.04^{\mathrm{b}}$ & 0.92 & 0.07 & 1.0 & 0.07 \\
\hline \multirow[t]{2}{*}{ C1 } & low & 3.150 & 22.1 & 76 & $32.3^{\mathrm{a}}$ & $17.0^{\mathrm{a}}$ & 15 & $6.35^{\mathrm{a}}$ & $7.11^{\mathrm{a}}$ & 0.01 & 0.14 & 1.0 & 0.09 \\
\hline & high & & 20.8 & 79 & $29.9^{b}$ & $15.7^{\mathrm{b}}$ & 18 & $6.10^{\mathrm{b}}$ & $8.07^{\mathrm{b}}$ & 0.53 & 0.11 & 1.0 & 0.05 \\
\hline \multirow[t]{2}{*}{$\mathrm{C} 2$} & low & 2.094 & 22.4 & 85 & $32.9^{a}$ & $17.6^{\mathrm{a}}$ & 16 & $6.29^{\mathrm{a}}$ & $7.38^{\mathrm{a}}$ & 0.96 & 0.13 & 0.9 & 0.10 \\
\hline & high & & 21.7 & 91 & $29.1^{b}$ & $15.9^{\mathrm{b}}$ & 19 & $6.01^{b}$ & $7.96^{\mathrm{b}}$ & 0.40 & 0.11 & 1.3 & 0.06 \\
\hline \multirow[t]{2}{*}{ C3 } & low & 3.657 & 22.4 & 91 & $34.1^{\mathrm{a}}$ & $18.3^{\mathrm{a}}$ & 15 & $6.13^{\mathrm{a}}$ & $7.23^{\mathrm{a}}$ & 0.42 & 0.13 & 0.9 & 0.11 \\
\hline & high & & 21.7 & 89 & $31.3^{b}$ & $16.3^{\mathrm{b}}$ & 17 & $6.04^{b}$ & $8.14^{\mathrm{b}}$ & 0.41 & 0.12 & 1.0 & 0.07 \\
\hline
\end{tabular}

" Significant difference $(p<0.05)$

fall period in September. The main substrate of the corresponding dammed site (A2) was sand and leaf pack. The undammed site at $900 \mathrm{~m}$ (B1) had the most varied habitat; boulder was the main substrate, followed by sand and cobble. Habitat at the corresponding dammed site (B2) was mainly cobble with leaf packs. The sand habitat at site B2 occurred near the check dam. Overflow of the 


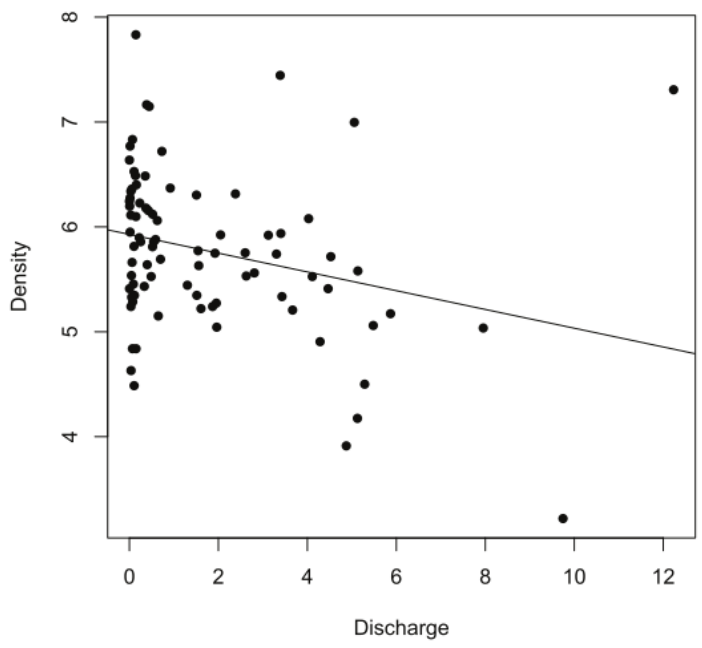

Fig. 5 Relationship between discharge $\left(\mathrm{m}^{3} / \mathrm{s}\right)$ and logtransformed density $\left(R^{2}=0.075, p<0.05\right)$ shows decrease in insect density with high discharge.

check dam at site B2 during August -December created a fast-flowing habitat for aquatic insects on the dam wall. At $500 \mathrm{~m}$ altitude, habitat diversity at the undammed site (C1) was lower than at the corresponding dammed sites (C2 and C3). The main substrate of $\mathrm{C} 1$ was bedrock, which was categorized as boulder. Leaf pack habitat was present and sampled only in January and February. Site C2 also had bedrock as the main substrate. Overflow from the dam wall at site $\mathrm{C} 2$ created a pool near the check dam where sand was deposited and sampled. Boulder habitat dominated at site C3, where cobble and streamside vegetation habitats were present during low flow periods.

Aquatic insect composition differed among each of the altitudes (Fig. 4a) and was also affected by check dams, although site B1 shared a few insect taxa with site B2 (Fig. 4b-d). Although communities varied with altitude, similar patterns of flow and dam effects on reducing insect density were found within the same altitude during low and high flow periods, as described below.

\section{Response of aquatic insects to high flow}

Conductivity, TDS and $\mathrm{pH}$ were significantly higher during low flow periods than during high flow periods, whereas dissolved oxygen significantly increased during high flow periods $(p<0.05)$ (Table 1). Although differences were not statistically significant, water temperature tended to be lower during high flow periods, whereas turbidity increased during high flows, except at altitude $1500 \mathrm{~m}$ sites. High flow was associated with reduced phosphate concentrations in the water. $\mathrm{Ni}$ trate concentrations increased in high flow except at site A2. During high flow periods, the proportion of unstable habitat (i.e., clay, sand and leaf pack) tended to increase in site A but decrease at sites B and C (Fig. 3).

Flow periods significantly affected aquatic insect density that significantly decreased with high flow periods (Fig. 5). Insect density at site A1 was slightly reduced by high flow. Insects found in the leaf packs and under cobbles of site A1 were reduced, whereas insects in gravel habitats increased during high flow periods (see Appendix for insect taxa). At site A2, the proportions of clay and sand habitats were higher during high flow periods than during low flow periods. Leaf pack habitat was proportionally reduced by high flow and the dominant insect taxa in leaf pack habitat were changed. At $900 \mathrm{~m}$, insects in leaf pack and boulder habitats were highly decreased during high flow. Both sites had declines in mayflies in the cobble habitat during high flow periods but the species differed between sites. At $500 \mathrm{~m}$, the streambed was mostly bedrock or boulder habitat and consequently, the diversity of aquatic insects was lower than at other altitudes during high flow periods. Although taxa were reduced at all the $\mathrm{C}$ sites during high flow periods, the taxa reduced at site $\mathrm{C} 1$ differed from those at the dammed sites.

\section{Response of aquatic insects to check dams}

Average water velocity at dammed sites was significantly lower than at undammed sites for all altitudes $(p<0.05)$. Average discharge was also lower at dammed sites compared with their corresponding undammed sites, except that site C3 had higher discharge than site $\mathrm{C} 1$ (Table 1 ). Lower velocity was significantly related to an increase in the proportion of unstable habitat $\left(R^{2}=0.32, p<0.01\right)$. Dammed sites had higher canopy cover, water turbidity and BOD than undammed sites. Dissolved oxygen and phosphate concentrations were higher at dammed sites, except at the $900 \mathrm{~m}$ sites.

Aquatic insect density was affected by check dams $\left(\chi^{2}=8.86, \mathrm{df}=1, p<0.01\right)$. Average insect density was lower at dammed sites compared with their corresponding undammed sites. Variation in insect density among dammed and undammed sites was associated with variation in habitat composition. Habitat composition of the dammed sites at 
sites A and C differed from the habitat composition at their corresponding undammed sites, whereas habitat composition at sites B1 and B2 were more similar (Fig. 3). The proportion of unstable habitat (clay, sand and leaf pack) in dammed sites was higher than in the corresponding undammed sites at all altitudes, and this increase in the proportion of unstable habitat was associated with a decrease in aquatic insect density. Clay and sand habitats had the lowest insect abundance among the habitat types (means of 12 and 13 individual/sample, respectively), whereas leaf pack habitat had the highest abundance (mean of 56 individual/sample). As a consequence, dammed sites had lower insect density than the corresponding undammed sites (Fig. 2).

Dammed and undammed sites sometimes supported different assemblages of insects. For example, site A1 and A2 had similar proportions of leaf pack habitat but had different taxa groups associated with these leaf pack habitats. At $900 \mathrm{~m}$, insect taxa associated with leaf pack and cobble habitats at the dammed site were higher than insects in boulder habitats. At $500 \mathrm{~m}$, the high proportion of boulder habitat at site $\mathrm{C} 1$ was associated with species adapted to fast flow, whereas the dammed sites (C2 and C3) had proportionally more insects that are typical of solid substrates.

\section{Combined effects of high flow and check dams on aquatic insects}

Velocity during high flow periods increased more at dammed sites than at undammed sites, except at site $\mathrm{C} 2$, where the velocity increase was similar to that of site C1 (Fig. 6). During high flow periods, dammed sites generally had less change in some physicochemical characteristics than undammed sites, i.e., water temperature, BOD, ammonia, nitrate and phosphate concentrations (Table 1). In contrast, conductivity, TDS, turbidity and dissolved oxygen generally changed more in dammed sites than in undammed sites during high flow periods.

During high flow periods, changes in habitat diversity differed between dammed and undammed sites (Fig. 3). For sites A1 and A2, high flow increased habitat diversity at the undammed site, but not in the dammed site. Site B1 had lower habitat diversity during high flow, in contrast with site B2 which had an increase in the proportion of leaf pack and boulder habitats. Habitat diversity of sites C2 and C3 changed because of high flow, whereas site C1 had similar habitat in both low and high flow conditions. Leaf pack habitat was increased
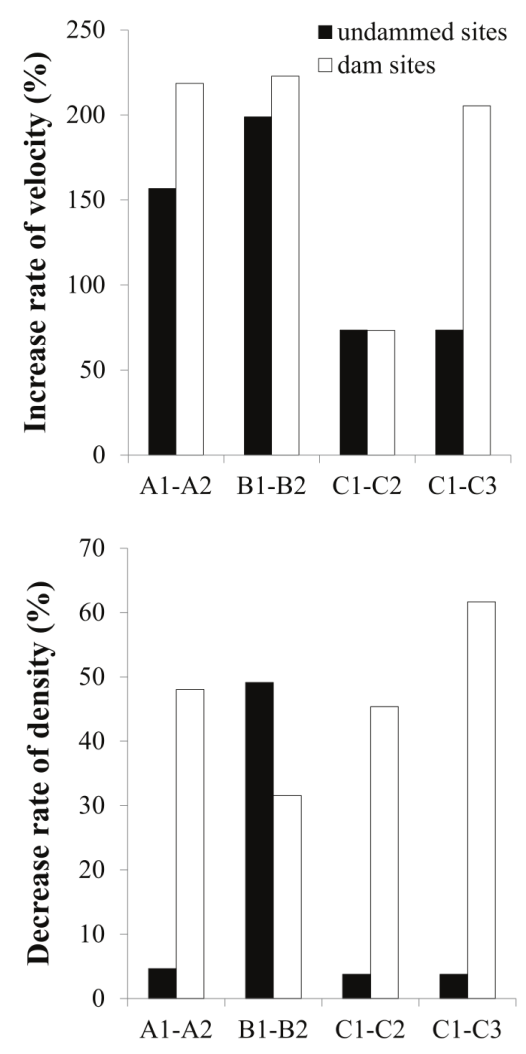

Fig. 6 Comparison of velocity changes between high and low flow periods. Dammed sites had higher percent velocity increases than the corresponding undammed site, except for site C2 that had the same percent increase. Higher percent increases at the dammed sites show higher change on velocity between high and low flow periods than at undammed sites. (b) Change in aquatic insect density between low and high flow periods at dammed and undammed sites. The percent decrease in density during high flow periods was higher at dammed sites than at the corresponding undammed sites, except for sites B1 and $\mathrm{B} 2$.

by check dams but decreased with high flow, except at site B2. Fine sediment (clay and sand habitats) was higher at dammed sites than the corresponding undammed sites, except at site B2, which had a lower ratio of fine sediment than site B1 during high flow periods. However, change in fine sediments (either increase or decrease) at dammed sites was greater than at undammed sites during periods of high flow.

High flow and flow alteration by check dams both reduced aquatic insect density (Fig. 2). Compared with the low flow periods, the decrease in insect density due to high flow at dammed sites 
Table 2 Aquatic insect composition at sampling sites was highly affected by high flow and check dams.

\begin{tabular}{|c|c|c|c|c|c|c|c|c|c|c|c|c|}
\hline & & \multicolumn{7}{|c|}{ Affected by high flow } & \multicolumn{4}{|c|}{ Affected by dam } \\
\hline & & $\mathrm{A} 1$ & $\mathrm{~A} 2$ & B1 & B2 & $\mathrm{C} 1$ & $\mathrm{C} 2$ & $\mathrm{C} 3$ & $\mathrm{~A} 2$ & B2 & $\mathrm{C} 2$ & C3 \\
\hline \multirow[t]{6}{*}{ Ephemeroptera } & Asionurus spp. & & + & & - & & & & & - & & \\
\hline & Baetis spp. & & & & & & & - & & & & - \\
\hline & Baetiella spp. & & & & & & & - & & - & & - \\
\hline & Epeorus spp. & & & & - & & & & & - & - & - \\
\hline & Isca spp. & + & & & - & & & & & + & & \\
\hline & Thalerosphyrus spp. & & & - & - & & & & & - & & \\
\hline Odonata & Zygonyx spp. & & & & & - & & & & & & \\
\hline \multirow[t]{2}{*}{ Plecoptera } & Etrocorema spp. & & & & & & & & & + & & \\
\hline & Nemoura spp. & & & & & & & & + & & & \\
\hline Hemiptera & Amemboa spp. & - & & & & & & & & & & \\
\hline \multirow[t]{9}{*}{ Trichoptera } & Agapetus spp. & + & & & - & & & & & - & & \\
\hline & Anisocentropus spp. & & & & & & & & - & & & \\
\hline & Ceratopsyche spp. & & & & & & - & & & + & & \\
\hline & Chimarra spp. & & & & & - & & & & & - & - \\
\hline & Hydropsyche spp. & & - & - & & & - & - & & & & - \\
\hline & Lepidostoma spp. & - & & - & - & & - & & - & - & - & \\
\hline & Polycentropus spp. & & & & & & & & + & & & \\
\hline & Setodes spp. & & & & & & - & & & & - & \\
\hline & Trichomacronema spp. & & & & & & & - & & & - & \\
\hline Coleoptera & Elmomorphus spp. & & & & & & - & & & & - & \\
\hline \multirow[t]{10}{*}{ Diptera } & Apistomyia spp. & & & & & + & & & & & - & - \\
\hline & Asuragina spp. & & & & - & & & & & - & & \\
\hline & Bezzia spp. & & - & & & & & & - & & & \\
\hline & Dicranomyia spp. & & & & & & & & - & & & \\
\hline & Limnophila spp. & - & & & & & & & & & & \\
\hline & Polypedilum spp. & & - & & & & & & + & & & \\
\hline & Rheotanytarsus spp. & & - & & & & & & - & & + & + \\
\hline & Simulium spp. & + & & - & - & + & - & - & & & - & - \\
\hline & Tanytarsus spp. & & & & & & - & & & & - & \\
\hline & Tvetenia spp. & & & & & - & & & & & & \\
\hline
\end{tabular}

was greater than the decrease at the corresponding undammed sites $\left(\chi^{2}=34.93-67.15\right.$, $\mathrm{df}=1, p<$ $0.01)$, except at the $\mathrm{B}$ sites $\left(\chi^{2}=7.86, \mathrm{df}=1\right.$, $p<0.01$ ).

The high decline in insect density at site A2 during high flow was primarily a result of the decrease in the leaf pack community. Insects at leaf packs at site C2 were also highly reduced during high flow. In addition, site $\mathrm{C} 2$ had reduced insects associated with sand habitat during high flow. Insects reduced during high flow at site C3 were mainly in boulder habitats. At site B2, the reduced density of insect during high flow was proportionally less than at the corresponding undammed site (B1). Density at B2 was largely maintained by caddisflies in the leaf pack habitat and communities in the cobble habitat. High flow at site C1 was associated with an increased abundance of black fly larva, which was reduced during high flow at the corresponding dammed sites (C2 and C3, Table 2).

\section{DISCUSSION}

The natural, typical annual flow regime in many tropical streams includes flood and drought, which correlate with monsoon rainfall events ${ }^{28,29}$. In this study, Huay Kaew Stream had two peaks of rainfall, in May and August-September, which produced two peaks of discharge in June and September. High discharge normally decreases the abundance of benthic organisms ${ }^{30}$, including aquatic insects in both undammed and dammed sites in this study. The movement of streambed substrates during high flows is a significant disturbance for benthic organisms ${ }^{31}$. Because these disturbances are often seasonable, organisms may have adapted life history, behaviour and morphology in response to natural cycle of floods and droughts ${ }^{29}$. For example, Lepidostoma hirtum, Hydropsyche pellucidula 
and $H$. siltalai have a univoltine life history with rapid growth before seasonally high flows and declines in density during high flow periods ${ }^{32}$. The number and diversity of drifting animals also increases during high flow ${ }^{31}$, which indicates substantial dislodgement. Benthic invertebrates may avoid the disturbance of high flow by moving to refuges that have lower shear stress ${ }^{31,33}$. Net-spinning caddisflies (Hydropsyche spp. and Trichomacronema spp.) can increase substrate stability by constructing their filtration net among substrate particles, which can provide refuges for aquatic invertebrates during floods ${ }^{34}$. A decrease in net-spinning caddisflies at $\mathrm{B}$ and $\mathrm{C}$ dammed sites may have impacted other insects through the loss of potential refuges. Species adapted to fast flow (such as Baetiella spp. and Simulium spp.) were also impacted by high flow. Although species adapted to fast flow may have stream-line body shapes and special attachment mechanisms ${ }^{35}$, flash floods associated with rain may sweep away some organisms, especially in mountain streams with high slopes, such as Huay Kaew Stream. Because site C1 has a mostly bedrock streambed characterized by both fast flow and few flow refuges, insects at this site were mostly species adapted to fast flow. Hence this site retained a higher insect density than the dammed sites (C2 and C3) during high flow periods.

Aquatic insect communities are influenced by the availability of appropriate habitats. Streambed characteristics are largely the result of spatial variation and intensity of water flow acting on parent materials or moving particles, which structure the habitat for aquatic insects ${ }^{36}$. Average discharge was inversely proportional to altitude but was reduced in dammed sites compared to undammed sites, although in comparison to sites $\mathrm{C} 1$ and $\mathrm{C} 2$, site $\mathrm{C} 3$ apparently gained water from subterranean flow. Flow reduction (both discharge and velocity) by dams directly impacts aquatic insect communities, especially filter-feeders, gathering collectors and scrap$\mathrm{ers}^{36}$ by decreasing food availability as particles are deposited above dams and by increasing the rate of drifting ${ }^{37}$. In addition, lowered flow reduces habitat diversity by introducing deposition of fine sediment that may coat all substrates ${ }^{17,37}$, such as cobbles and gravels. Although natural low flow periods also occurred at undammed sites, a lower flow with longer duration occurred in dammed sites. In the study stream, a decline in insect community density and changes in composition were associated with an increase in unstable habitats (fine sediments and leaf packs) due to the presence of check dams. Many types of insects avoid sediments deposited on rocky substrates $^{38}$, indeed, few insects were collected in clay and sand habitats.

In addition to the effects of flow reduction at dammed sites and seasonal high flow in reducing insect abundance, the higher magnitude of change in water velocity at dammed sites than at the corresponding undammed sites also affected aquatic insects. An abrupt increase in flow reduces taxon richness and increases the number of drifting invertebrates compared to a more stepwise flow increase that provides time for invertebrate responses (e.g., seeking refuges) ${ }^{39}$. The leaf pack and fine sediments that were the main substrates at dammed sites are unstable substrates for aquatic insects because these substrates are easily mobilized by high flow. The organisms in unstable habitats at dammed sites were more readily flushed than insects in other habitats where they could hide in refuges, whereas undammed sites retained the same, flood-resistant community, which is more adapted to high flows. Thus Death and Winterbourn ${ }^{40}$ found high species richness and density in habitats with high stability. The leaf pack habitat had the second highest insect abundance among the various habitats, following the boulder habitat. Thus a reduction in leaf pack habitat produced declines in many insects. Examples of these flow and habitat effects were evident in our study system. In the case of the first-order stream (site A), high rainfall that eroded more fine sediment from surrounding riparian area into the stream during high flow periods reduced insect abundance. The dammed site A2 had greater sediment deposition from erosion of the surrounding area, resulting in lower insect abundance than at site A1. In contrast, high flow at lower altitudes swept leaf pack and fine sediment from below dams, where these habitats dominated, leading to higher insect loss compared to the undammed sites. The small proportion of leaf pack remaining at site C2 during high flow was associated with an overall large decrease in insect density, whereas site B2 retained more leaf pack habitat and had a lower reduction in insect density during the high flow periods. When most leaf packs were disrupted during high flow periods, the number of Lepidostoma spp. was much lower than during low flow periods, when leaf packs formed a more stable habitat. Lepidostoma spp. consumes leaves and uses leaves to construct cases and this genus occurs mainly in leaf pack habitats $^{35}$. Alternatively, the reduction of Lepidostoma abundance during high flow periods may indicate seasonal emergence of adults and avoidance 
of high flows. For undammed sites, although fine sediment and leaf packs were removed by floods, the remaining larger substrates provided refuges for insects. Complex benthic structure provides refuges for benthic invertebrates during small spates ${ }^{41}$. Although the unstable habitats of site C3 were quite similar during low and high flow periods, high flows decreased habitat diversity, causing a decrease in insect abundance, as substrate mobilization (e.g., rolling rocks) disturbs insects, including hydropsychids $^{42}$. In contrast, an increase in cobble habitat from broken dam materials near the check dam of site B2 increased insect abundance. These cobbles increased the area of stable habitat for insect refuges from not only high flow but also from predators ${ }^{33}$, and promoted formation of insect-abundant leaf packs. In addition, an increase in sand habitat and overflow from a dam at site B2 during high flow periods that increased habitat diversity also reduced insect loss in comparison to at the corresponding undammed site.

\section{CONCLUSIONS}

High flow often reduces aquatic insect density in Huay Kaew Stream at all altitudes and the decline of insects was locally intensified by check-dams although the insect community at each altitude was different. Alteration of hydrologic conditions by check dams revealed impacts on the density of aquatic insects. The effects of check dams on streams may be reduced by the erosion of pile-rock dams, which diversifies habitats and provides flow refuges. Most of the check dams were constructed five years before the study and the geomorphology of the channel had adjusted to the dam-affected flow regime. Although the effects of check dams on the habitat and aquatic insects were not major, our study included just a small number of the many check-dams along Huay Kaew Stream. Thus the cumulative effects of all the many check dams in the stream can cause large overall changes. The study was a good representative of the effects of small dams on mountain streams because the stream location within the National Park had low human disturbance. In contrast, most streams in Thailand are in areas of impacted habitat, and large dams or even small dams that are close together can impact streambed recovery. Check dams that have high dam walls obstruct flow connectivity, which is necessary for downstream drift and food source transportation. Check dams that restrict flow to water seeping under the dam, such as site B2, may have a low impact on biota but the check dam may affect the normal downstream transport of organic materials, which may impact downstream organisms.

Acknowledgements: We thank Jittima Rungwattanasophon, Kanlayarat Jantawong, Worradorn Phairuang, Wongphan Promwong, Titinan Pothong and Nichanan Thongdej for help with field work. The Aquatic Insect Research Unit of Chiang Mai University provided laboratory support and facilities. The Thailand Research Fund supported funding through the Royal Golden Jubilee Ph.D. Programme (Grant No. PHD/0143/2550).

\section{REFERENCES}

1. Vannote RL, Minshall GW, Cummins KW, Sedell JR, Cushing CE (1980) The river continuum concept. Can J Fish Aquat Sci 37, 130-7.

2. Newbury RW, Bates DJ (2006) Dynamics of flow. In: Hauer FR, Lamberti GA (eds) Methods in stream ecology, Elsevier, pp 79-101.

3. Smock LA (2006) Macroinvertebrate dispersal. In: Hauer FR, Lamberti GA (eds) Methods in stream ecology, Elsevier, pp 465-87.

4. Greathouse EA, Pringle CM, Holmquist JG (2006) Conservation and management of migratory fauna: dams in tropical streams of Puerto Rico. Aquat Conserv: Mar Freshw Ecosyst 16, 695-712.

5. Poff NL, Allan JD, Bain MB, Karr JR, Prestegaard KL, Richter BD, Sparks RE, Stromberg JC (1997) The natural flow regime. BioSci 47, 769-84.

6. Wetzel RG (2001) Limnology: lake and river ecosystems. Gulf Professional Publishing.

7. Strayer DL, Dudgeon D (2010) Freshwater biodiversity conservation: recent progress and future challenges. J N Am Benthol Soc 29, 344-58.

8. Grill G, Lehner B, Lumsdon AE, MacDonald GK, Zarfl C, Liermann CR (2015) An index-based framework for assessing patterns and trends in river fragmentation and flow regulation by global dams at multiple scales. Environ Res Lett 10, 1-15.

9. Zarfl C, Lumsdon AE, Berlekamp J, Tydecks L, Tockner K (2015) A global boom in hydropower dam construction. Aquat Sci 77, 161-70.

10. Allen DC, Galbraith HS, Vaughn CC, Spooner DE (2013) A tale of two rivers: implication of water management practices for mussel biodiversity outcomes during droughts. AMBIO 42, 881-91.

11. Boyero L, Ramírez A, Dudgeon D, Pearson RG (2009) Are tropical streams really different? J N Am Benthol Soc 28, 397-403.

12. Haines-Young $R$, Potschin M (2010) The link between biodiversity, ecosystem services and human wellbeing. In Raffaelli D, Frid C (eds) Ecosystem ecology: a new synthesis, Cambridge, pp 110-39.

13. Pringle CM, Freeman MC, Freeman BJ (2000) Regional effects of hydrologic alterations on riverine 
macrobiota in the New World: tropical-temperate comparison. BioSci 50, 807-23.

14. Boulton AJ, Boyero L, Covich AP, Dobson M, Lake S, Pearson $R$ (2008) Are tropical streams ecologically different from temperate streams? In Dudgeon $\mathrm{D}$ (ed) Aquatic ecosystems: tropical stream ecology, Elsevier Science, pp 257-84.

15. Ceneviva-Bastos M, Prates DB, Romero RM, Bispo PC, Casatti L (2017) Trophic guilds of EPT (Ephemeroptera Plecoptera, and Trichoptera) in three basins of the Brazilian Savanna. Limnologica $63,11-7$.

16. Taniwaki RH, Piggott JJ, Ferraz SFB, Matthaei CD (2017) Climate change and multiple stressors in small tropical streams. Hydrobiologia 793, 41-53.

17. Bunn SE, Arthington AH (2002) Basic principles and ecological consequences of altered flow regimes for aquatic biodiversity. Environ Manage 30, 492-507.

18. Suriyawong P, Thapanya D, Bergey EA, Chantaramongkol P (2015a) Macroinvertebrate community response to habitat alteration in a regulated mountain stream in Doi Suthep-Pui National Park, Thailand. Entomological Research Bulletin 31, 32-40.

19. Suriyawong P, Thapanya D, Bergey EA, Chantaramongkol P (2015b) Seasonal variation of aquatic insect communities and environmental characteristics in a regulated mountain stream. Paper presented at the $3^{\text {rd }}$ EnvironmentAsia International Conference on Towards International Collaboration for an Environmentally Sustainable World, Bangkok, 17-19 June, pp 240-50.

20. Balian EV, Segers H, Lévèque C, Martens K (2008) The freshwater animal diversity assessment: an overview of the results. Hydrobiologia 595, 627-37.

21. Carter JL, Resh VH, Hannaford MJ, Myers M (2006) Macroinvertebrates as biotic indicators of environmental quality. In: Hauer FR, Lamberti GA (eds) Methods in Stream Ecology, Elsevier, pp 805-31.

22. Ward JV (1989) The four-dimensional nature of lotic ecosystems. J N Am Benthol Soc 8, 2-8.

23. Kiffney PM, Clements WH (1996) Effects of metals on stream macroinvertebrate assemblages from different altitudes. Ecol Appl 6, 472-81.

24. Suren AM (1994) Macroinvertebrate communities of streams in western Nepal: effects of altitude and land use. Freshwater Biol 32, 323-36.

25. Monaghan KA, Peck MR, Brewin PA, Masiero M, Zarate E, Turcotte P, Ormerod SJ (2000) Macroinvertebrate distribution in Ecuadorian hill streams: the effects of altitude and land use. Archiv für Hydrobiologie 149, 421-40.

26. Jacobsen D, Schultz $R$, Encalada A (1997) Structure and diversity of stream invertebrate assemblages: the influence of temperature with altitude and latitude. Freshwater Biol 38, 247-61.

27. R Core Team (2013) R: A Language and environment for Statistical Computing. Retrieved 12 January
2016, from R Foundation for Statistical Computing, Vienna, Austria website: www.r-project.org

28. Dudgeon D (2000) The ecology of Tropical Asian rivers and streams in relation to biodiversity conversation. Annu Rev Ecol Syst 31, 239-63.

29. Lytle DA, Poff NL (2004) Adaptation to natural flow regimes. Trends in Ecology and Evolution, 19(2), 94100.

30. Vörösmarty CJ, Green P, Salisbury J, Lammers RB (2000) Global water resources: vulnerability from climate change and population growth. Science $\mathbf{2 8 9}$, 284-8.

31. Bond NR, Downes BJ (2003) The independent and interactive effects of fine sediment and flow on benthic invertebrate communities characteristic of small upland streams. Freshwater Biol 48, 455-65.

32. Basaguren A, Riano P, Pozo J (2002) Life history patterns and dietary changes of several caddisfly (Trichoptera) species in a northern Spain stream. Archiv für Hydrobiologie -Hauptbände 155, 23-41.

33. Lancaster J (2000) Geometric scaling of microhabitat patches and their efficacy as refugia during disturbance. J Anim Ecol 69, 442-57.

34. Cardinale BJ, Gelmann ER, Palmer MA (2004) Netspinning caddisflies as stream ecosystem engineers: the influence of Hydropsyche on benthic substrate stability. Funct Ecol 18, 381-7.

35. Dudgeon D (1999) Tropical Asian streams: Zoobenthos, ecology and conservation, Hong Kong University Press.

36. Walter AW, Post DM (2011) How low can you go? Impacts of a low-flow disturbance on aquatic insect communities. Ecol Appl 21, 163-74.

37. Dewson ZS, James ABW, Death RG (2007) A review of the consequences of decreased flow for instream habitat and macroinvertebrates. J N Am Benthol Soc 26, 401-15.

38. McClelland WT, Brusven MA (1980) Effects of sedimentation on the behaviour and distribution of riffle insects in a laboratory stream. Aquat Insect 2, 161-9.

39. Imbert JB, Perry JA (2000) Drift and benthic invertebrate responses to stepwise and abrupt increases in non-scouring flow. Hydrobiologia 436, 191-208.

40. Death RG, Winterbourn MJ (1995) Diversity pattern in stream benthic invertebrate communities: the influence of habitat stability. Ecology 76, 1446-60.

41. Robson BJ (1996) Small spate disturbance and the complexity of habitat architecture in mountain river, Tasmania. Mar Freshwater Res 47, 851-5.

42. Bond NR, Downes BJ (2000) Flow-related disturbance in streams: an experimental test of the role of rock movement in reducing macroinvertebrate population densities. Mar Freshwater Res 51, 333-7. 